When Pride Meets Envy: Is Social Superiority Portrayal in Luxury Adverting Perceived as Prestige or Arrogance?

\author{
Billy Sung* \\ School of Marketing, Curtin University \\ Kent Street, Bentley, WA 6102, Perth, Australia \\ (+6189266 2852) \\ billy.sung@curtin.edu.au
}

\author{
Ian Phau \\ School of Marketing, Curtin University \\ Kent Street, Bentley, WA 6102, Perth, Australia \\ $(+61892664014)$ \\ ian.phau@cbs.curtin.edu.au
}

*Correspondence concerning this article should be address to B. Sung, School of Marketing, Curtin University, WA 6102, Perth, Australia

(billy.sung@curtin.edu.au) 


\begin{abstract}
This paper draws on the theoretical underpinnings of envy and pride in examining the effectiveness of social superiority portrayal in luxury advertising. Across two studies, benign (malicious) envy led consumers to perceive social superiority portrayal as an expression of authentic (hubristic) pride and, in turn, increased (reduced) luxury perception and positive brand attitude. These findings were replicated for both dispositional (Study 1 and 2) and state feeling of envy (Study 2), regardless of whether envy was self-reported or manipulated. These findings were found to be consistent in a comparison between luxury and premium brands. Taken together, this paper is the first to examine: (1) consumer responses toward social superiority portrayal in luxury advertising, (2) the interactive effect of envy and pride perceptions on luxury perception and brand attitude, and (3) the effectiveness of using social superiority portrayal as an advertising strategy for luxury and premium brands.
\end{abstract}

Keywords: envy, pride, social superiority, perception of luxury 


\section{When Pride Meets Envy: Is Social Superiority Portrayal in Luxury Adverting Perceived as Prestige or Arrogance?}

Advertisements for luxury brands commonly portray images of successful, sophisticated, and confident individuals expressing their social superiority. For example, the campaign for the Boy handbag collection by Chanel conveys the theme of social superiority by depicting individuals with exquisite expressions of pride, arrogance, and confidence. However, empirical evidence supporting the effectiveness of social superiority portrayal in luxury advertising is scant. One exception was a pilot study which showed that an individual's exposure to a story of a similar successful other increased the desire for luxury goods (Mandel, Petrova \& Cialdini, 2006). The prevalent use of social superiority portrayal in luxury advertising calls for more research to examine the effectiveness of this strategy in evoking perceptions of luxury and positive evaluations of a brand. The current research addresses this gap by drawing on two emotions related to expressions and perceptions of social superiority: pride and envy.

Across different cultures, the expression of social superiority has been recognized as a result of pride (Antonetti \& Maklan, 2014; Cheng, Tracy, \& Henrich, 2010; Cheng, Tracy, Foulsham, Kingstone, \& Henrich, 2013; Keh, Park, Kelly, \& Du, 2016). Recent research suggests that consumers may perceive expressions of social superiority as either prestige (positively) or arrogance (negatively) (Cheng et al., 2013; McFerran, Aquino, \& Tracy, 2014; Tracy \& Robins, 2007; Wang, Chow, \& Luk, 2013).

Tracy and Robins (2007) termed the positive facet of pride as authentic pride and the negative facet as hubristic pride. In fact, McFerran et al. (2014) demonstrated that only the experience of authentic pride but not hubristic pride motivates luxury consumption. Examining how and why consumers perceive the portrayal of social superiority in a positive (authentic pride) or negative (hubristic pride) light therefore is important to optimize the effectiveness of using such a portrayal in luxury advertising. 
The most prevalent emotional experience associated with pride and the perception of others' social superiority is envy. This is because envy is an emotion evoked by upward social comparison (Smith \& Kim, 2007; Van de Ven, Zeelenberg, \& Pieters, 2012). Lange and Crusius (2015) identified two facets of pride associated with different types of envy. Authentic pride is associated with benign envy, which entails positive thoughts, increased effort, and a desire to obtain and advantage over others. Hubristic pride is associated with malicious envy, which entails negative thoughts and a desire to sabotage the advantage of others (Lange \& Crusius, 2015; Van de Ven et al., 2012). In fact, pride and envy has been used by luxury brands to evoke consumers' desire for their product. For instance, Cartier's "the art of being unique" and Bottega Veneta's “when your own initials are enough" taglines are designed to evoke envy and anticipated pride toward uniqueness and superior status.

As such, this paper draws on the recent theoretical advances in the research of envy and pride to examine consumers' responses toward social superiority portrayal in luxury advertising. Specifically, the objectives of this paper are threefold. First, the paper tests the relationship between envy and perception of pride. Second, it examines the interactive effect of envy and pride on perceived luxury and positive brand attitude. Third, it investigates the effectiveness of using social superiority portrayal in evoking the perception of luxury and positive brand attitude in both luxury and premium brands. The rest of the paper is structured as follows. A review of the relevant literature on envy and pride is presented to guide the hypotheses development. This will be followed by a description of the research methods, results, and discussion of the two studies. The paper will conclude with a general discussion of the theoretical and managerial implications as well as limitations of the studies.

\section{RELEVANT LITERATURE AND HYPOTHESIS DEVELOPMENT}

\section{Pride}


Evolutionary psychology theories suggest that emotions are formed and evolved to support formation and maintenance of relationship as well as social hierarchies (see Lange \& Cursius, 2015 for a review). Pride and its expression are recognized as a result of increased social status or social superiority (Cheng et al., 2010; 2013; Tracey \& Robins, 2008). The expression of pride is characterized by expanded poster, head tilted back and non-Duchenne smile (Tracey \& Robins, 2008). Prior research has shown that individuals readily recognize, identify, and distinguish such an expression of pride as a signal of social superiority (e.g., Cheng, 2013; Lang \& Crusius, 2015; McFerran, Aquino, \& Tracey, 2014; Tracey \& Robins, 2008). Thus, individuals communicate and perceive social superiority, especially in competitive environment, through pride (Cheng et al., 2010; 2013; Tracy, Shariff, Zhao, \& Henrich, 2013).

Expression of pride can be interpreted in a positive or a negative light. Authentic pride is associated with confidence, accomplishment, and effort-driven achievement, while hubristic pride is associated with arrogance, conceit, and narcissistic self-aggrandizement (Keh et al., 2016; Lange \& Crusius, 2015; McFerran et al. 2014; Tracy \& Robins, 2007; 2008; Wang et al., 2013). Given this, expression of authentic pride is perceived to be prestigious and respectful, whereas expression of hubristic pride is perceived to be dominating and aggressive (Cheng et al., 2010; 2013). Thus, consumers may perceive the portrayal of social superiority in luxury advertising as either an expression of authentic or hubristic pride, which ultimately may lead to different reactions. The current research therefore examine how consumer perceive and interpret social superiority display in luxury advertising as an expression of authentic and hubristic pride.

\section{Envy}

The strongest and most prevalent emotional response toward social superiority is envy (Lange \& Crusius, 2015; Smith \& Kim, 2007). Envy is a negative emotional response toward a situation whereby an individual makes an upward social comparison when he or she lacks 
another's superior status, achievement, or possession (Smith \& Kim, 2007; Van de Ven, Zeelenberg, \& Pieters, 2011). Its evolutionary function is therefore to motivate individuals to reduce the differences between themselves and an envied person with social superiority (Van de Ven, Zeelenberg, \& Pieters, 2009). The current research therefore examines how envy affect consumers' perception of social superiority display in luxury advertising.

Consistent with the research on pride, envy has been shown to be a multifaceted emotional response that motivate pro-social (positive) behavior or socially harming (negative) behviour. Benign envy entails positive thought and behavior that reflect one's desire to increase effort in attaining another's superior status. Whereas, malicious envy entails negative thought and behavior that reflect one's hostility and desire to undermine another's superior status. Similarly, Van de Ven et al. (2011) demonstrated that benign envy motivates consumers to narrow the gap with the superior other by striving to obtain the envious product, thereby elevating their social status. On the other hand, malicious envy motivates consumers to level the difference by undermining the products owned by the envied person with social superiority. Thus, the experience of benign and malicious envy may determine how consumers perceive and respond to the portrayal of social superiority in luxury advertising.

\section{The Interaction between Pride and Envy}

The current research examines whether benign (malicious) envy leads consumers to attribute the portrayal of social superiority to the expression of authentic (hubristic) pride and therefore increases (attenuates) perceive luxury and positive brand attitude. Given the link between envy and pride, Lange and Crusius (2015) manipulated the type of pride expressed by a superior other and measured participants' envy levels. Findings demonstrated that authentic (hubristic) pride leads to a likable (unlikable) impression and in turn, evokes benign (malicious) envy. However, whether different types of envy may alter subsequent perceptions of pride or social superiority displays remains unexplored in the existing literature. This insight is important 
because advertisements of luxury brands commonly involve the portrayal of pride and social superiority following the consumption of luxury products. Furthermore, consumers generally perceive luxury consumption as a signal of hubristic instead of authentic pride ( McFerran, Aquino, \& Tracy, 2014; Shariff \& Tracy, 2009). Thus, examining how different types of envy influence perception of social superiority and pride is pivotal in understanding consumers' responses toward luxury branding.

Extending from Lange and Crusius' (2015), the present research examines whether benign (malicious) envy leads consumers to subsequently perceive the portrayal of social superiority as a signal of authentic (hubristic) pride. In fact, Lange and Crusisus' findings (2015; Study 1) provided indirect support for this proposition. An envied person was perceived to display authentic (hubristic) pride when the participants recalled an experience of benign (malicious) envy. The upward-moving motivation accompanying benign envy and the downward-pulling motivation accompanying malicious envy suggest that social superiority of others is perceived in a positive (negative) light following benign (malicious) envy. Following this, the current research tests the effect of malicious and benign envy on perceived luxury and positive brand attitude following the exposure of a luxury advertisement portraying social superiority.

\section{Luxury Perception}

Luxury brands are explicitly marketed to appear rare, exclusive, prestigious, and authentic (Phau \& Prendergast, 2000; Turunen \& Laaksonen 2011; Tynan, McKechnie, \& Chhuon, 2010). The glamour and distinction that these brands generate appeal to consumers' desire to signal their accomplishments, success, or social superiority (Mandel, Petrova, \& Cialdini, 2006; McFerran, Aquino, \& Tracy, 2014). An inherent and important goal of luxury branding is to establish, maintain, and leverage luxury perceptions of the brand (Hagtvedt \& Patrick, 2008; Vigneron \& Johnson, 2004). 
Authentic pride appears to be more closely related to luxury perception when compared to hubristic pride. Authentic pride has been shown to be the prosocial and achievementorientated facet of pride whereas hubristic pride has been shown to be the antisocial and aggressive facet of pride (Cheng et al., 2013; McFerran, Aquino, \& Tracy, 2014; Shariff \& Tracy, 2009; Tracy \& Robins, 2007). Thus, authentic pride is related to perceived prestige, confidence, and self-worth (Lange \& Crusius, 2015). Consistent with this, McFerran et al. (2014) identified that authentic, not hubristic pride, serves as a motivator of luxury consumption. Further, Lange and Crusius (2014) showed that benign envy reflects the hope of success whereas malicious envy reflects the fear of failure. Thus, it is hypothesized that:

$\boldsymbol{H}_{1}$ : Benign (malicious) envy leads to greater perception of luxury, and this is mediated by authentic (hubristic) pride (see Figure 1)

[Insert Figure 1 about here]

\section{Attitude Toward the Luxury Brand}

Brand evaluation has been a key measure of consumer responses (Till \& Busler, 2000). Although past research has explored the addictive effect of envy and pride (McFerran, Aquino, \& Tracy, 2014; Van de Ven et al., 2011), the present study is the first to examine the interactive effects of envy and pride on the perception of luxury and evaluation of luxury brands. Both benign and malicious envy are negative in valence; however benign envy is a result of liking and admiration for the envied target, and malicious envy is a result of hostility toward the envied target (Tai, Narayanan, \& McAllister, 2012). In line with this, Van de Ven et al. (2011) suggested that benign envy motivates consumers to purchase an envied product whereas malicious envy motivates the purchase of alternative brands. Similar findings have been reported for the distinction between authentic and hubristic pride. When compared to hubristic 
pride, authentic pride not only attracts greater liking but also respect, cooperativeness, and social acceptance (Cheng et al., 2010 2013). Thus, it is hypothesized that:

H$_{2}$ : Benign (malicious) envy leads to greater positive attitude toward the brand and this is mediated by authentic (hubristic) pride.

[Insert Figure 2 about here]

\section{The Role of Brand Type}

Premium brands have become more prevalent over the past decade (Schnittka, 2015). When compared to value brands, premium brands charge a price premium and offer a higher quality product (Palmeira \& Thomas, 2011; Wiedmann, Hennings, \& Siebels, 2009). They are considered, however, to be middle-range brands when compared to luxury brands that offer higher price premiums and superior quality. Yet, premium brands often need to justify their price premium by leveraging on the perception of luxury (Truong, McColl, \& Kitchen, 2009; Vigneron \& Johnson, 2004; Zoellner \& Tobia, 2015). Research on envy largely has been conducted on premium brands such as the Apple iPhone (Van de Ven et al., 2011). However, no prior research has examined whether envy has an effect on luxury perception and attitude toward premium brands. The current paper extends this stream of research and provides a better understanding of envy by considering its effect on consumers' perception of authentic and hubristic pride. Specifically, this paper will compare the hypothesized effects $\left(\mathrm{H}_{1}\right.$ and $\left.\mathrm{H}_{2}\right)$ within the contexts of both premium and luxury brands. Thus, a research question of this paper is:

$\boldsymbol{R Q}_{1}$ : Are the hypothesized effects $\left(H_{1}\right.$ and $\left.H_{2}\right)$ significant across both luxury and premium brands?

\section{STUDY 1}




\section{Method}

Participants. Following the sample size of Lange and Crusius' study (2015), 150 undergraduate students from a metropolitan university who participated for course credit were recruited. Their ages ranged from 18 to 41 years, with a mean age of 19.76 years $(S D=3.41)$. All participants had previous intention to purchase from the brands depicted in Study 1.

Procedure and Design. Study 1 adopted a within-subjects design to test $\mathrm{H}_{1}$ and $\mathrm{H}_{2}$, and examine whether the hypothesized relationships differ between a luxury and a premium brand $\left(\mathrm{RQ}_{1}\right)$. Participants were randomly presented with genuine advertisements from two luxury brands (Calvin Klein and Armani) and two premium brands (Lee and Levi's). These brands were chosen as they were identified as the most desirable luxury brands and non-luxury counterparts by a similar sample in a pilot study.

Each advertisement depicted the brand name and portrayed a male and a female model expressing social superiority with the product. After seeing each advertisement, participants evaluated the brand on a perception of brand luxury scale $(\alpha=.91)$ and a brand attitude scale $(\alpha=.92)$ adapted from Hagtvedt and Patrick (2008). A simple Sudoku exercise then was used as a filler task. After that, participants were randomly presented with the advertisements again and reported whether the models appeared to express hubristic pride and authentic pride (Tracy $\&$ Robins, 2007). Finally, participants completed a dispositional measure of benign envy $(\alpha=$ $.83)$ and malicious envy $(\alpha=.81)$ (Lange \& Crusius, 2014). To examine the hypothesized relationships, difference scores were created between authentic and hubristic pride as well as between dispositional benign and malicious envy.

\section{Results and Discussion}

Using the bootstrapping approach, a mediation analysis based on 10,000 bootstrapping samples was conducted (Hayes, 2013; Montoya \& Hayes, 2015) and found support for $\mathrm{H}_{1}$ and $\mathrm{H}_{2}$. For the luxury brands, dispositional benign (malicious) envy had a positive (negative) indirect 
effect on positive brand attitude through authentic (hubristic) pride $(b=.06,95 \%$ CI $[.022$, .126]). A similar indirect effect was found to be significant for the perception of brand luxury ( $b=.03,95 \%$ CI $[.007, .088])$. Thus, benign (malicious) envy led consumers to perceive the portrayal of social superiority to be an expression of authentic (hubristic) pride. Further, this was found to increase (reduce) perception of luxury as well as brand attitude, supporting $\mathrm{H}_{1}$ and $\mathrm{H}_{2}$. For the premium brand, the indirect effect of envy on brand attitude through perception of pride also was significant $(b=.04,95 \%$ CI $[.009, .083])$. However, the indirect effect on brand luxury was not significant for the non-luxury brands. Addressing $\mathrm{RQ}_{1}$, the results suggest that the hypothesized relationship between benign (malicious) envy and authentic (hubristic) pride only increases (decreases) positive brand attitude but not perceived luxury.

The findings of Study 1 not only supported the association between benign (malicious) envy and authentic (hubristic) pride, but also demonstrated the interactive effect of envy and pride on brand attitude. This highlights the importance of managing consumer envy toward social superiority portrayal in the advertising of both luxury and premium brands. These findings, however, are limited to dispositional envy.

Study 2 was designed to examine branding strategies that evoke the feeling of benign envy. Van de Ven et al. (2012) showed that benign and malicious envy are evoked by different subjective appraisal patterns. High-control, potential appraisal serves as a key antecedent of benign envy but not malicious envy. Thus, Study 2 extended the findings from Study 1 by using control potential appraisal to manipulate participants' experience of benign envy toward the portray of social superiority in luxury branding.

\section{STUDY 2}

\section{Method}


Participants. Again, following the sample size of Lange and Crusius' study (2015), 120 participants from an online American consumer panel were recruited. Their ages ranged from 20 to 70 years, with a mean age of 34.25 years $(S D=10.69)$.

Procedure and design. Study 1 followed a 2 (luxury brand vs. premium brand) x 2 (high vs. low control/benign envy) between-subjects design. To alleviate any extraneous effect, all participants were presented with the same fashion advertisements that depicted a male and a female model displaying social superiority through their consumption of the product. McFerran et al. (2014) showed that Ralph Lauren and Lee are equally familiar to consumers in United States but the two brands differ reliably on perception of brand luxury. Therefore, the brand name of either Ralph Lauren (luxury) or Lee (premium) was superimposed onto the advertisement.

Van de Ven et al. (2012) suggested that high-control consumers perceive the envied product to be attainable whereas low-control consumers perceive the envied product to be exclusive and unattainable. To manipulate participants' control appraisal, the advertisement in Study 2 either advertised a unique collection of the season's new arrival (high control/benign envy) or an exclusive collection available for a limited time (low control/benign envy).

Participants were randomly presented with one of the four advertisements. They were asked to report how the advertisement made them feel in terms of control (Van de Ven et al., 2012) as well as their feelings of benign envy ( $\alpha=.88$; Van de Ven et al., 2012). Following the procedures of Study 1, they were asked to indicate whether the models in the advertisement expressed authentic pride ( $\alpha=.89$; Tracy \& Robin, 2007) and completed the dispositional measure of benign envy ( $\alpha=.89$; Lange $\&$ Crusius, 2014).

\section{Results and Discussion}

The high-control condition reported higher control $(M=4.17, S D=1.26)$ than the low-control condition $(M=3.50, S D=1.20, p=.047)$. High-control participants also reported higher 
feelings of benign envy $(M=3.32, S D=1.34)$ than low-control participants $(M=2.48, S D=$ $1.68, p=.028)$. The results demonstrate that the manipulation was successful, whereby promoting the envied product to be unique (vs. exclusive) and as new arrival (vs. available for a limited time) elicited higher benign envy.

Using the bootstrapping approach, a mediation analysis based on 10,000 bootstrapping samples was conducted (Hayes, 2013). The results supported $\mathrm{H}_{1}$ and $\mathrm{H}_{2}$. Dispositional benign envy was entered as a covariate to examine the effect of feeling of benign envy over and above dispositional benign envy. Feeling of benign envy had a significant positive indirect effect on positive brand attitude $(b=.08,95 \%$ CI $[.009, .188])$ and brand luxury perception $(b=.11$, $95 \%$ CI $[.015, .222])$ through perception of authentic pride. Thus, a feeling of benign envy led participants to perceive the portrayal of social superiority in the advertisements as an expression of authentic pride. This, in turn, enhanced brand luxury perception and positive brand attitude, supporting $\mathrm{H}_{1}$ and $\mathrm{H}_{2}$. However, when the brand name was entered as a moderator in the mediation analysis, the moderated mediations were not significant. Thus, similar indirect effects of envy on luxury perception and positive attitude were observed for the premium brand.

To provide further support for the hypotheses, the analyses on dispositional benign envy were replicated following the analyses in Study 1. In line with the findings from Study 1, dispositional benign envy had a significant positive indirect effect on positive brand attitude ( $b$ $=.08,95 \% \mathrm{CI}[.009, .188])$ and brand luxury perception $(b=.11,95 \% \mathrm{CI}[.015, .222])$ through perception of authentic pride. These findings replicated the results from Study 1 and provided further support for $\mathrm{H}_{1}$ and $\mathrm{H}_{2}$. In fact, the results from Study 2 suggest that the interactive effect of envy and pride is not limited to luxury brands but also is observed for premium brands. Taken together, the findings of Study 2 on both dispositional and feeling of envy supported the two hypotheses. 


\section{GENERAL DISCUSSION}

The existing literature lacks a clear understanding of how social superiority portrayals affect consumer responses toward luxury advertising. This is particularly important for managers of luxury brands as social superiority portrayal is commonly used in their advertising. This paper fulfilled the three objectives set forth in its introduction. First, the current results demonstrated that benign (malicious) envy is associated with authentic (hubristic) pride. Specifically, benign (malicious) envy predisposes consumers to perceive social superiority portrayal in luxury advertising to be an expression of authentic (hubristic) pride.

Second, the current findings demonstrated that benign (malicious) envy and authentic (hubristic) pride has an interactive effect that increases (reduces) luxury perception and positive brand attitude. Third, the current findings indicated that social superiority portrayal is effective for luxury and premium brands only when the individual is disposed to or experiences benign but not malicious envy. In fact, Study 2 demonstrated that simply promoting the advertised product as attainable can ensure the effectiveness of social superiority portrayal by evoking benign instead of malicious envy.

The hypothesized effects of envy were observed for both luxury and premium brands (Study 1 and 2), suggesting that the two facets of envy are key determinants of how consumers respond to social superiority portrayal. Furthermore, these findings were replicated in a correlational study on genuine advertisements (Study 1) and an experiment that successfully manipulated consumers' experience of benign envy (Study 2). In addition, support for the hypotheses were found for both dispositional envy (Study 1) and state feeling of envy (Study 2). Taken together, this paper demonstrated that envy drives consumers to perceive the same portrayal of social superiority in either a positive or a negative light. This in turn, results in a spillover effect onto consumers' perception of luxury and positive attitude toward the advertised brand. 


\section{Theoretical Implications}

The current findings provide several theoretical implications. First, the findings address a critical question that has been inadequately examined in the extant literature. Specifically, the present study is the first to show that social superiority portrayal can lead to positive and negative outcomes depending on the consumers' experience of envy.

Second, this paper builds on prior research exploring the emotional antecedent of luxury consumption. The current study is the first to demonstrate the differential effects of benign and malicious envy on consumers' interpretation of social superiority portrayal as an expression of authentic and hubristic pride. In fact, the current findings extended Van de Ven et al.'s studies (2009; 2011; 2012) in four ways: (1) demonstrating the interactive effects of envy and pride, (2) confirming such effects on both luxury and premium brands, (3) examining such effects on perception of luxury and positive brand attitude, and (4) replicating such effects on dispositional and state feeling of envy.

Furthermore, the current findings confirm and provide further insights into the complementary relationship between envy and pride. Lange and Crusius (2015) suggested that authentic and hubristic pride expression may evoke the experience of benign and malicious envy, respectively. However, the results of the current study suggest that the cause-and-effect between envy and pride is more convoluted. Specifically, benign and malicious envy lead individuals to perceive the same display of social superiority as an expression of authentic and hubristic pride, respectively.

Third, this paper contributes to the literature by confirming antecedents of envy and pride. Specifically, high-control potential appraisal was shown to be an antecedent of benign envy. This extends Van de Ven et al.'s study (2012) by showing that manipulation of control potential appraisal can be achieved through advertising strategies such as promoting the brand to be attainable. Furthermore, the findings also contribute to the antecedent and consequence 
of pride. Specifically, this paper extends prior research on pride (e.g., Antonetti \& Maklan, 2014; Lange \& Crusius, 2015; McFerran, Aquino \& Tracy, 2014; Tracy \& Robins, 2007; 2008) by showing that: (1) social superiority portrayal is perceived as an expression of pride, (2) envy determines whether expression of pride is interpreted to be authentic or hubristic, and (3) authentic and hubristic pride have a significant impact on luxury perception and positive brand attitude. In fact, the current findings confirm the relationship between authentic pride expression and prestige (e.g., Tracy \& Robins, 2008) by demonstrating that perception of authentic pride increases the perceived luxury of the brand.

\section{Managerial Implications}

Several key managerial implications can be drawn. First, this paper suggests that portrayal of social superiority in luxury advertising does not always result in positive consumer responses. It may evoke malicious envy and lead consumers to perceive the brand as arrogant and snobbish. Given that social superiority portrayal is commonly used in luxury advertising, marketers must carefully manage consumers' interpretation of such portrayals. A solution for this challenge is to design strategies that portray authentic pride using less aggressive, arrogant, and dominant expressions of pride and social superiority. For instance, Patek Phillippe's advertisements usually feature a smiling parent and children engaging in an activity or life moment to which consumers can relate. This may alleviate feelings of malicious envy and increase the likelihood of evoking benign envy and positive responses.

Second, the present findings suggest that managing consumers' experience of emotion and perception of other customers' emotional expression are important for both luxury and premium brands. Specifically, the current findings indicate that the experience of benign and malicious envy is an important determinant of consumers' perceptions of luxury and brand evaluation. Thus, advertisers must design their branding and communication strategies to evoke benign, not malicious, envy to ensure positive consumer responses. This can be achieved 
through the use of likable endorsers that deserve their success and prestige. For instance, Rolex usually features successful athletes such as Roger Federer and David Beckham in their advertisements.

Third, the present research is the first to demonstrate a possible advertising strategy to evoke consumers' benign envy instead of malicious envy toward social superiority portrayal in luxury advertising. Study 2 demonstrated that advertising a luxury brand to be attainable and available may evoke benign envy that, in turn, results in more positive consumer responses. Interestingly, this simple strategy remains effective regardless of consumers' predisposition to feel envy. Thus, luxury brands need to convey not only the exclusivity and quality of the luxury brand, but also its attainability, to maintain consumers' hope.

Fourth, findings of the current study add to the growing literature on ways to enhance the luxury perception of a brand (e.g., Hagtvedt \& Patrick, 2008). This study is the first to demonstrate that luxury perception of a brand can be affected by the pride expression and social superiority portrayal of brand endorsers. These findings suggest that a social display of arrogance and dominance by endorsers may affect consumers' luxury perception of an endorsed brand. Thus, marketers should monitor and manage the image of endorsers to build and maintain the positive image of a brand.

\section{Limitations and Future Research Directions}

It is important to note that the present study is not without its limitations. First, inconsistent results were found for the indirect effect of envy on the luxury perception of premium brands. A possible explanation of this inconsistency is that dispositional envy has a weaker effect on luxury perception compared to experience of envy. This is supported by the results in Study 2, which show that state feeling of envy has a robust effect on luxury perception above and beyond dispositional envy. Nevertheless, future research is needed to examine the boundary condition of the effect of envy and pride on luxury perception. 
Furthermore, future research can extend the findings by examining different portrayals of pride and social superiority in luxury branding. In this study, social superiority portrayal through the endorsers and their expressions in the advertisements was examined. Thus, an interesting avenue for future research is to examine the effect of different social superiority expressions displayed by the endorser in luxury branding. Different expression of pride such as single-fisted, double-fisted, and akimbo poses also can be investigated (for a review, see Lange \& Crusius, 2015). In fact, the findings suggest that social superiority portrayal in luxury advertising can evoke negative responses. The trigger of negative emotional responses in luxury advertising is an interesting avenue to explore in the future. Specifically, future research should examine how different advertising cues and appeals may elicit negative emotions that deter intention to purchase. More importantly, future research should also compare the effectiveness of different branding and communication strategies to portray social superiority in a positive way.

Another extension of the present research is to compare the effectiveness of social superiority portrayal on private products (e.g., food and furniture) and public products (e.g., fashion and automobiles). Prior research (e.g., Wang \& Griskevicius, 2015; Wiedmann et al., 2009) has empirically demonstrated that luxury consumption is used as a signal of status and uniqueness. Thus, consumers are more inclined to purchase public rather than private luxury products. In fact, envy should be more prominent when other's social superiority is publicly displayed. Thus, future research can examine whether or not the observed relationships in the present research are moderated by product category, in particular, public and private luxury products. 


\section{REFERENCES}

Antonetti, P., \& Maklan, S. (2014). Exploring postconsumption guilt and pride in the context of sustainability. Psychology \& Marketing, 31(9), 717-735. doi: 10.1002/mar.20730

Cheng, J. T., Tracy, J. L., \& Henrich, J. (2010). Pride, personality, and the evolutionary foundations of human social status. Evolution and Human Behavior, 31(5), 334-347. doi: 10.1016/j.evolhumbehav.2010.02.004

Cheng, J. T., Tracy, J. L., Foulsham, T., Kingstone, A., \& Henrich, J. (2013). Two ways to the top: Evidence that dominance and prestige are distinct yet viable avenues to social rank and influence. Journal of Personality and Social Psychology, 104(1), 103-125. doi: $10.1037 / \mathrm{a} 0030398$

Keh, H. T., Park, I. H., Kelly, S., \& Du, X. (2016). The effects of model size and race on Chinese consumers' reactions: A social comparison perspective. Psychology \& Marketing, 33(3), 177-194. doi: 10.1002/mar.20864

Hagtvedt, H., \& Patrick, V. M. (2008). Art infusion: The influence of visual art on the perception and evaluation of consumer products. Journal of Marketing Research, 45(3), 379-389.

Hayes, A. F. (2013). Introduction to mediation, moderation, and conditional process analysis: A regression-based approach. Guilford Press.

Lange, J., \& Crusius, J. (2015). Dispositional envy revisited: Unraveling the motivational dynamics of benign and malicious envy. Personality and Social Psychology Bulletin, 41(2), 284-294.

Lange, J., \& Crusius, J. (2015). The tango of two deadly sins: The social-functional relation of envy and pride. Journal of Personality and Social Psychology, 109(3), pp. 453-472. doi: $10.1037 /$ pspi0000026

Mandel, N., Petrova, P. K., \& Cialdini, R. B. (2006). Images of success and the preference 
for luxury brands. Journal of Consumer Psychology, 16(1), 57-69. doi: 10.1207/s15327663jcp1601_8

McFerran, B., Aquino, K., \& Tracy, J. L. (2014). Evidence for two facets of pride in consumption: Findings from luxury brands. Journal of Consumer Psychology, 24(4), 311-322. doi: 10.1016/j.jcps.2014.03.004

Montoya, A. K., \& Hayes, A. F. (2015, May). Estimating and testing indirect effects in withinsubject mediation analysis: A path-analytic framework. In Annual Convention of the Association for Psychological Science, New York, NY.

Palmeira, M. M., \& Thomas, D. (2011). Two-tier store brands: the benefic impact of a value brand on perceptions of a premium brand. Journal of Retailing, 87(4), 540-548.

Phau, I., \& Prendergast, G. (2000). Consuming luxury brands: the relevance of the 'rarity principle'. The Journal of Brand Management, 8(2), 122-138.

Schnittka, O. (2015). Are they always promising? An empirical analysis of moderators influencing consumer preferences for economy and premium private labels. Journal of Retailing and Consumer Services, 24, 94-99.

Shariff, A. F., \& Tracy, J. L. (2009). Knowing who's boss: Implicit perceptions of status from the nonverbal expression of pride. Emotion, 9(5), 631-639. doi: 10.1037/a0017089

Smith, R. H., \& Kim, S. H. (2007). Comprehending envy. Psychological Bulletin, 133(1), 46-64. doi: 10.1037/0033-2909.133.1.46

Tai, K., Narayanan, J., \& McAllister, D. J. (2012). Envy as pain: Rethinking the nature of envy and its implications for employees and organizations. Academy of Management Review, 37(1), 107-129. doi: 10.5465/amr.2009.0484

Till, B. D., \& Busler, M. (2000). The match-up hypothesis: Physical attractiveness, expertise, and the role of fit on brand attitude, purchase intent and brand beliefs. Journal of advertising, 29(3), 1-13. 
Tracy, J. L., \& Robins, R. W. (2007). The psychological structure of pride: A tale of two facets. Journal of Personality and Social Psychology, 92(3), 506-525. doi: $10.1037 / 0022-3514.92 .3 .506$

Tracy, J. L., \& Robins, R. W. (2008). The nonverbal expression of pride: Evidence for crosscultural recognition. Journal of Personality and Social Psychology, 94(3), 516-530. doi: 10.1037/0022-3514.94.3.516

Tracy, J. L., Shariff, A. F., Zhao, W., \& Henrich, J. (2013). Cross-cultural evidence that the nonverbal expression of pride is an automatic status signal. Journal of Experimental Psychology: General, 142(1), 163.

Truong, Y., McColl, R., \& Kitchen, P. J. (2009). New luxury brand positioning and the emergence of masstige brands. Journal of Brand Management, 16(5-6), 375-382.

Turunen, L., \& Laaksonen, P. (2011). Diffusing the boundaries between luxury and counterfeits. Journal of Product \& Brand Management, 20(6), 468-474.

Tynan, C., McKechnie, S., \& Chhuon, C. (2010). Co-creating value for luxury brands. Journal of Business Research, 63, 1156-1163. doi: 10.1016/j.jbusres.2009.10.012

Van de Ven, N., Zeelenberg, M., \& Pieters, R. (2009). Leveling up and down: The experiences of benign and malicious envy. Emotion, 9(3), 419-429. doi:

\section{$10.1037 / \mathrm{a} 0015669$}

Van de Ven, N., \& Zeelenberg, M., \& Pieters, R. (2011). The envy premium in product evaluation. Journal of Consumer Research, 37(6), 984-998. doi: 10.1086/657239

Van de Ven, N., Zeelenberg, M., \& Pieters, R. (2012). Appraisal patterns of envy and related emotions. Motivation and Emotion, 36(2), 195-204. doi: 10.1007/s11031-011-9235-8

Vigneron, F., \& Johnson, L. W. (2004). Measuring perceptions of brand luxury. The Journal of Brand Management, 11(6), 484-506. doi: 10.1057/palgrave.bm.2540194

Wang, X., Chow, C. W., \& Luk, C. L. (2013). Does service employee arrogance discourage 
sales of luxury brands in emerging economies? Psychology \& Marketing, 30(10), 918933. doi: 10.1002/mar.20655

Wang, Y., \& Griskevicius, V. (2013). Conspicuous consumption, relationships, and rivals: Women's luxury products as signals to other women. Journal of Consumer Research, 40(5), 834-854.

Wiedmann, K. P., Hennigs, N., \& Siebels, A. (2009). Value-based segmentation of luxury consumption behavior. Psychology \& Marketing, 26(7), 625-651. doi: 10.1002/mar.20292

Zoellner, F., \& Schaefers, T. (2015). Do price promotions help or hurt premium-product brands?. Journal of Advertising Research, 55(3), 270-283. 


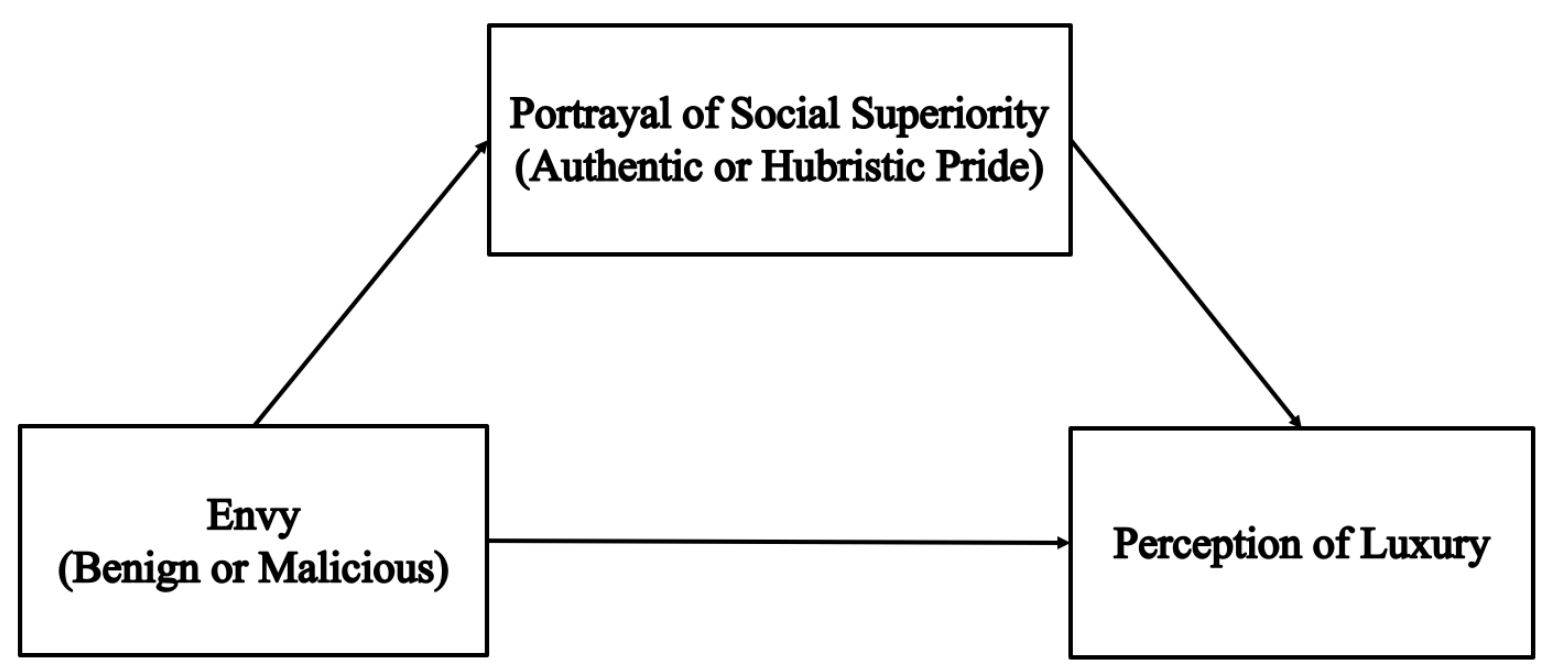

Figure 1. Framework for Hypothesis 1. 


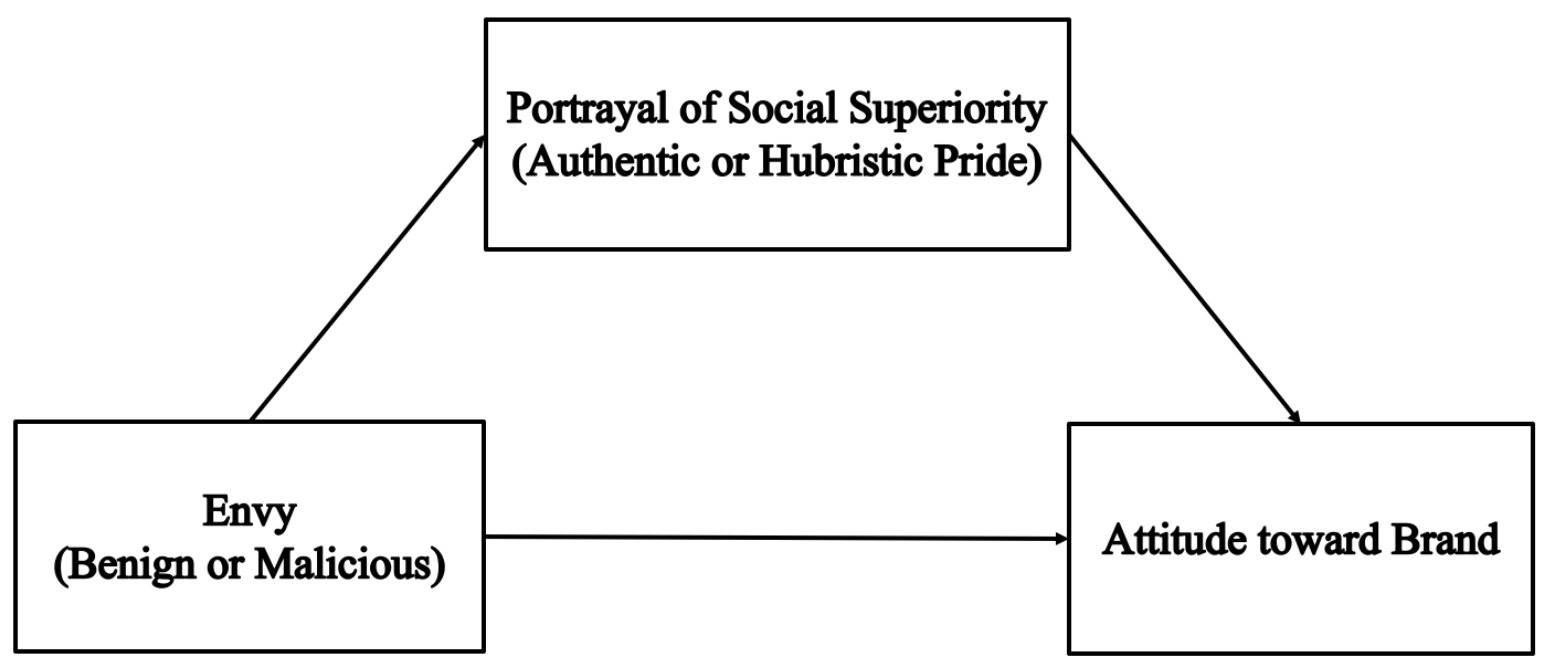

Figure 2. Framework for Hypothesis 2. 